\title{
EVALUATING THE PERFORMANCE OF FARMER COMPANIES IN SRI LANKA: A CASE STUDY OF RIDI BENDI ELA FARMER COMPANY
}

\author{
M. Esham ${ }^{1}$ and K. Usami ${ }^{2}$
}

\begin{abstract}
Farmer companies in Sri Lanka were established with the view to accelerating commercialization in non-plantation agriculture. However, due to various constraints they have failed to achieve expected objectives. Hence, in this study, we review the potential of a successful farmer company from the aspects of farmer perception, farmer company management and performance. A field survey and secondary published data were used for the study. The study revealed that farmer perception of the farmer company as a service provider and awareness gap between shareholders and the farmer company coupled with restriction on share capital ownership limited the ability of the farmer company to expand the share capital and its commercial activities. Therefore, there is a need to strengthen the capital base of the farmer companies to enable the expansion of commercial activities and attract more farmer participation. In this regard, the active participation of the agribusiness industry should be sought considering the need to preserve the independence of the farmer company.
\end{abstract}

Keywords: Farmer Company, Commercialization of Agriculture, Farmer Perception

\section{INTRODUCTION}

To improve productivity and competitiveness of the non-plantation agriculture in Sri Lanka, participation of the agribusiness industry is imperative. Contract farming is considered as a viable option for the agribusiness industry investment and market integration within Sri Lankan agriculture (Somaratne and Ratnayake, 2004). Due to small scale of farming operations in the non-plantation agriculture, contract farming activities are not easily monitored and managing contractual arrangements with many small farmers entails high cost (Dunham, 1995). Moreover, there is strong power imbalance between the small farmers and the agribusiness companies (Porter and PhilipsHoward, 1995; Esham et al. 2006). Therefore, organizing small farmers into collective groups was seen as a strategy to reduce contract management cost and power imbalance (Little and Watts, 1994; Esham and Usami, 2005; Esham et al. 2006). As an important initiative in this direction, the National Development Council (NDC) of the government of Sri Lanka in 1995 recommended unification of small farmers under farmer companies. However, the performance of farmer companies over the past decade has been below expectations. Several constraints that account for this situation are: (1) politicization of farmer companies; (2) lack of managerial and entrepreneurial skills due to poor recruitment of management staff; (3) lack of sound plans and poor management by incompetent board of directors without professional advice; (4) lack of proper mechanisms to monitor and evaluate; and (5) mistrust between farmer company management and farmers (Senanayake, 2002).

\footnotetext{
${ }^{1}$ Senior lecturer, Department of Agribusiness Management, Faculty of Agricultural Sciences, Sabaragamuwa University of Sri Lanka, Belihuloya, Sri Lanka

${ }^{2}$ Professor, Faculty of Agriculture, Yamaguchi University, 1677-1 Yoshida, Yamaguchi-shi, 753-8515, Japan
} 
Therefore, in view of these constraints and the importance of farmer companies as formal collective groups to facilitate contract farming and other farmers-agribusiness linkages, this study aims at reviewing the potential through analyzing the present state and issues of a successful farmer company. Particular attention were paid to evaluating farmers' perception of the farmer company and financial performance of the farmer company due to the importance of these two aspects as a measure of state of farmer participation and an indicator of farmer company sustainability respectively. In this paper, we examine the Ridi Bendi Ela Farmer Company as it is one of the farmer companies established to pilot test the concept of farmer companies in Sri Lanka.

\section{METHODOLOGY}

For the case study, an unstructured interview schedule was used to collect data from the Ridi Bendi Ela Farmer Company officials, namely general manager and agriculture manager. Data from thirty five farmers living in the Ridi Bendi Ela irrigation scheme were also collected using an unstructured interview schedule pertaining to farmer household characteristics, agricultural background and farmers' perception of the Ridi Bendi Ela Farmer Company. The questions used to measure farmer perception were worded as follows: Do you wish the farmer company to be a service provider rather than a commercial entity? Do you expect dividends? Do you think that the farmer company has replaced the farmer organizations? Are you satisfied with the commercial activities organized by the farmer company? Are you satisfied with irrigation management? Are you aware of activities (group loan, input sales, seed paddy and broiler production) organized by the farmer company?

Farmers were randomly selected from the 11 farmer organizations (from each farmer organization two to four farmers) in the Ridi Bendi Ela irrigation scheme. Other information were collected during discussions with officials of other farmer companies and agencies involved in promoting farmer companies such as the Irrigation Management Division (IMD), Mahaweli Authority (MASL), Export Development Board (EDB) and the agribusiness companies. In addition, the annual reports and published/unpublished reports relating to the Ridi Bendi Ela Farmer Company were used as secondary sources.

\section{Brief History of Farmer Companies in Sri Lanka}

Farmer companies are investor-owned companies established under the companies act as people's companies. They are registered as people's companies to safeguard against possible private ownership by imposing restrictions on membership and share trading. Only farmers and other stakeholders involved in agriculture living within a particular geographical region can become shareholders and shares cannot be traded except among farmers eligible for membership. In addition, the maximum number of shares one can own is limited to $10 \%$ of shares issued at a given time according to the relevant provision of the act. 
Table 01: Background and characteristics of farmer companies in Sri Lanka

\begin{tabular}{|c|c|c|c|c|}
\hline Promoter & Background and aims & Examples & Major Activities & $\begin{array}{l}\text { No of } \\
\text { shareholders }\end{array}$ \\
\hline $\begin{array}{l}\text { Department } \\
\text { of Agriculture }\end{array}$ & $\begin{array}{l}\text { Assisted the formation of } \\
\text { about } 32 \text { farmer companies. } \\
\text { Originated from interest } \\
\text { groups which were mainly } \\
\text { farmer organizations } \\
\text { coming under the agrarian } \\
\text { service centers. Main aim } \\
\text { was commercialization }\end{array}$ & $\begin{array}{l}\text { Hiriyala } \\
\text { Farmer } \\
\text { Company }\end{array}$ & $\begin{array}{l}\text { Provide inputs, } \\
\text { Credit facilities, } \\
\text { Seed paddy } \\
\text { production }\end{array}$ & 1,800 \\
\hline $\begin{array}{l}\text { Ministry of } \\
\text { Irrigation }\end{array}$ & $\begin{array}{l}\text { Assisted the establishment } \\
\text { of about } 8 \text { farmer companies } \\
\text { based on major irrigation } \\
\text { schemes. Apart from } \\
\text { commercialization, } \\
\text { irrigation management was } \\
\text { another objective }\end{array}$ & $\begin{array}{l}\text { Rajangana } \\
\text { ya Farmer } \\
\text { Company } \\
\text { Ride Bendi } \\
\text { Ela } \\
\text { Farmer } \\
\text { Company }\end{array}$ & $\begin{array}{l}\text { Provide inputs, } \\
\text { Paddy purchasing, } \\
\text { Milk collection, } \\
\text { Irrigation } \\
\text { management } \\
\text { Credit facilities, } \\
\text { Provide inputs, } \\
\text { Contract farming, } \\
\text { Irrigation } \\
\text { management }\end{array}$ & 2,234 \\
\hline $\begin{array}{l}\text { Mahaweli } \\
\text { Authority }\end{array}$ & $\begin{array}{l}\text { Established about } 4 \text { farmer } \\
\text { companies based on major } \\
\text { irrigation schemes. } \\
\text { Originated from farmer } \\
\text { federations in the Mahaweli } \\
\text { scheme. Main aims were } \\
\text { commercialization and } \\
\text { irrigation management }\end{array}$ & $\begin{array}{l}\text { Elahera } \\
\text { Mahaweli } \\
\text { Farmer } \\
\text { Company }\end{array}$ & $\begin{array}{l}\text { Provide inputs, } \\
\text { Credit facilities, } \\
\text { Irrigation } \\
\text { management }\end{array}$ & 215 \\
\hline $\begin{array}{l}\text { Export } \\
\text { Development } \\
\text { Board }\end{array}$ & $\begin{array}{l}\text { Assisted the establishment } \\
\text { of } 36 \text { companies with the } \\
\text { objective of linking the rural } \\
\text { producers with the } \\
\text { exporters. At present, only } \\
\text { two companies are } \\
\text { operating }\end{array}$ & $\begin{array}{l}\text { Dambadeni } \\
\text { ya Export } \\
\text { Production } \\
\text { Village }\end{array}$ & $\begin{array}{l}\text { Manufacturing of } \\
\text { tea packages }\end{array}$ & 1,500 \\
\hline
\end{tabular}

Table 02: Farm household characteristics

\begin{tabular}{ll}
\hline Item & Mean/Percentage \\
\hline Age (household head) & 43.3 years \\
Education (schooling) & 8.3 years \\
Family size & 5.1 persons \\
Farm size & 1.37 ha \\
Low land area & 0.78 ha \\
Land allocated for paddy & \\
$\quad$ Maha & $99 \%$ \\
$\quad$ Yala & $70 \%$ \\
\hline
\end{tabular}


To understand the background of farmer companies in Sri Lanka, Table 1 summarizes the background, aims, activities and characteristics of farmer companies and export production villages initiated by various government agencies in Sri Lanka. Although farmer companies in Sri Lanka came into existence in the late 1990s, the history of farmer companies goes back to the early 1980s when the government of Sri Lanka introduced the concept of people's companies. The EDB took the initiative to establish Export Production Villages (EPVs) with the aim of integrating the village level producers with the exporters. Under this program about 36 EPVs were established of which about 20 were involved in the production of agricultural products. Another notable initiative was the United State Agency for International Development (USAID) sponsored Shared Control of Natural Resource project under which two farmer companies; Huruluwewa Farmer Company and Nilwala Farmer Company were established as pilot projects (Wijayaratna, 1997). In addition, the National Development Council (NDC) also conducted pilot programs on the concept of farmer companies in two major irrigation schemes, namely Ridi Bendi Ela and Uda Walawe. Based on these experiences, several other government agencies like the Department of Agriculture, Ministry of Irrigation and Mahaweli Authority promoted farmer companies based on the people's company concept in the late 1990s. The most common approach adopted by the Department of Agriculture in establishing farmer companies was to form interest groups and once viable business ventures were identified to develop them into farmer companies. In 17 districts, 85 interest groups were formed, 32 of which were transformed into farmer companies (Batuwitage, 2001). The Ministry of Irrigation and the Mahaweli Authority developed farmer companies based on the existing farmer organizations and block farmer federations in the irrigation schemes with the aims of handing over part of the operation and maintenance of the irrigation scheme and to accelerating commercialization of agriculture. As of December 2003 there was a total of 59 farmer companies and 33 EPVs registered with the Registrar of Companies. However, only few of these farmer companies and two EPVs are active at present.

\section{The Ridi Bendi Ela Farmer Company}

\section{Background and history}

The Ridi Bendi Ela farmer company is located in the Ridi Bendi Ela irrigation scheme in the northwestern province of Sri Lanka. Ridi Bendi Ela is an ancient irrigation system renovated in 1950's. The total command area of the system is 2,483 ha and about 2,796 families live in this system (Hussain and Perera, 2004). The Ridi Bendi Ela Farmer Company was established in 1998 by the Irrigation Management Division of the Ministry of Irrigation and Power in order to pilot test the farmer company concept with the aim of commercializing agriculture through handing over the operation and maintenance of the irrigation system. In the process of establishing this company, the start-up capital and operational cost for three years was borne by the government.

The farmer shareholders are mainly from the 11 farmer organizations representing the irrigation scheme. Even non-members of the farmer 
organizations can become shareholders given that they are legal settlers in the irrigation scheme as share ownership is restricted to legal inhabitants of the Ridi Bendi Ela irrigation scheme. The nominal value of a share is Rs 10 and to become a shareholder, it is necessary to own a minimum of 10 shares. Moreover, to involve in the activities of the farmer company, it is necessary to own 25 to 40 shares. Shareholders have increased from 430 in 1998 to 2,234 in 2004, implying that about $80 \%$ of the total 2,796 farming families living in the scheme are already shareholders of the farmer company. Accordingly, the share capital of the farmer company has steadily increased from Rs. 183, 450 in 1999 to Rs. 839,303 in 2004.

\section{Agriculture background in the irrigation scheme}

Table 02 presents some characteristics of farm households in the irrigation scheme. The average farmer is around 43 years old. Farmers living in the scheme are literate and on the average a farm household head has attended school for 8.3 years. On the average farmers own about 1.37 ha of land, of which 0.78 ha is irrigated mainly for paddy cultivation. In the Maha season (wet season), almost the entire command area of 2,450 ha is cultivated, while in the Yala season (dry season) only about $65 \%$ of the area is cultivated due to lack of rainfall. Paddy is the main crop cultivated in both the Maha and Yala seasons as $99 \%$ and $70 \%$ of lowland area are allocated for paddy production in the Maha and Yala seasons respectively. Vegetables, green/black gram, cowpea and maize are the other major crops grown by farmers, particularly in the Yala season.

\section{Structure and management}

Seven farmer directors elected by the shareholders at the annual general meeting manage the Ridi Bendi Ela Farmer Company. The directors are elected on majority vote; one director is elected as the chairperson. The board of directors is supported by an externally recruited management team headed by a general manager. The general manager is the chief executive officer (CEO) of the company and is a professionally qualified officer appointed by the board of directors. The general manager is responsible to the board of directors.

As shown in Figure 01, the company has a functional organizational structure with five sections such as agriculture, livestock, credit, administration and water resources. A professionally qualified officer heads each of the five sections. Out of the five sectional heads four are university graduates. The company has 18 employees working in various capacities from general manager to driver.

\section{Activities}

\section{(1) Commercialization of agriculture}

To meet the commercialization objectives, the Ridi Bendi Ela Farmer Company has started many activities involving the farmer shareholders (Table 03). Agricultural inputs sales, seed paddy production, group loan program and basmati rice production are the major revenue generating commercial activities undertaken by the company. The company either directly involves or acts as a facilitator in developing farmers-agribusiness linkages (Figure 02). In broiler and maize production the company acts as a facilitator of the linkage between 
farmers and agribusiness firms. The farmer company selects suitable farmers from its shareholders and enters into a contract with the agribusiness firm on behalf of the farmers. In general, the company distributes inputs, provides extension service with the assistance of the firm's extension officers, monitors, and assists the agribusiness firm to collect the produce. In the basmati rice production, seed paddy production and vegetable seed production programs, the company enters into a market specification contract with a supermarket chain to market basmati rice and with the agrarian service centers to market seed paddy and vegetable seeds under the company's own brand name. In these operations, the company provides all inputs on credit and free extension services to the farmers as shareholders.

At present, therefore, the company is able to fulfill input requirements for about 1,000 ha and extension needs for one third of the irrigation scheme. Agricultural inputs are provided by the main sales center owned by the company and the other nine sub-sales centers financed by the company and managed by private entrepreneurs. The farmers are able to buy agricultural inputs at a lower price compared to the open market, as the company only retains a low profit margin to cover up its operational costs.

\section{(2) Group loan program}

The group loan program is the core business of the Ridi Bendi Ela Farmer Company. Interest receipts from the group loan program accounted for about 33\% of the operating profits in the financial year 2003/2004. To be eligible for the group loan, farmers need to form small groups with a minimum of three members. The group members are jointly liable for the default of repayment. The credit is delivered in material and the farmers are not paid in cash. Farmers can buy inputs equivalent to the loan amount, which is Rs 12,350 per hectare of paddy cultivation (2003/2004 Maha season) from the main sales center or any of the nine sub-sales centers.

As shown in Table 04, the popularity of the group loan program has grown with the number of shareholders participating in the group loan program doubling and the amount of loan distributed significantly increasing over the last five years. The performance of the group loan program in terms of loan recovery is mediocre as the loan recovery rate is not satisfactory. Despite the group's joint liability to repay the loan, the low loan recovery can be attributed to the farmers' perception of the farmer company as a service provider.

Moreover, except some micro-credit schemes implemented by private financial institutions and some NGOs, low credit recovery is an inherent feature in Sri Lanka mainly due to politically motivated government policies where time-to-time governments in power write-off farmer credit for political gains. Given its importance as the core business of the Ridi Bendi Ela Farmer Company, failure to increase the credit recovery rate can have far-reaching implications for the sustainability of the farmer company. 


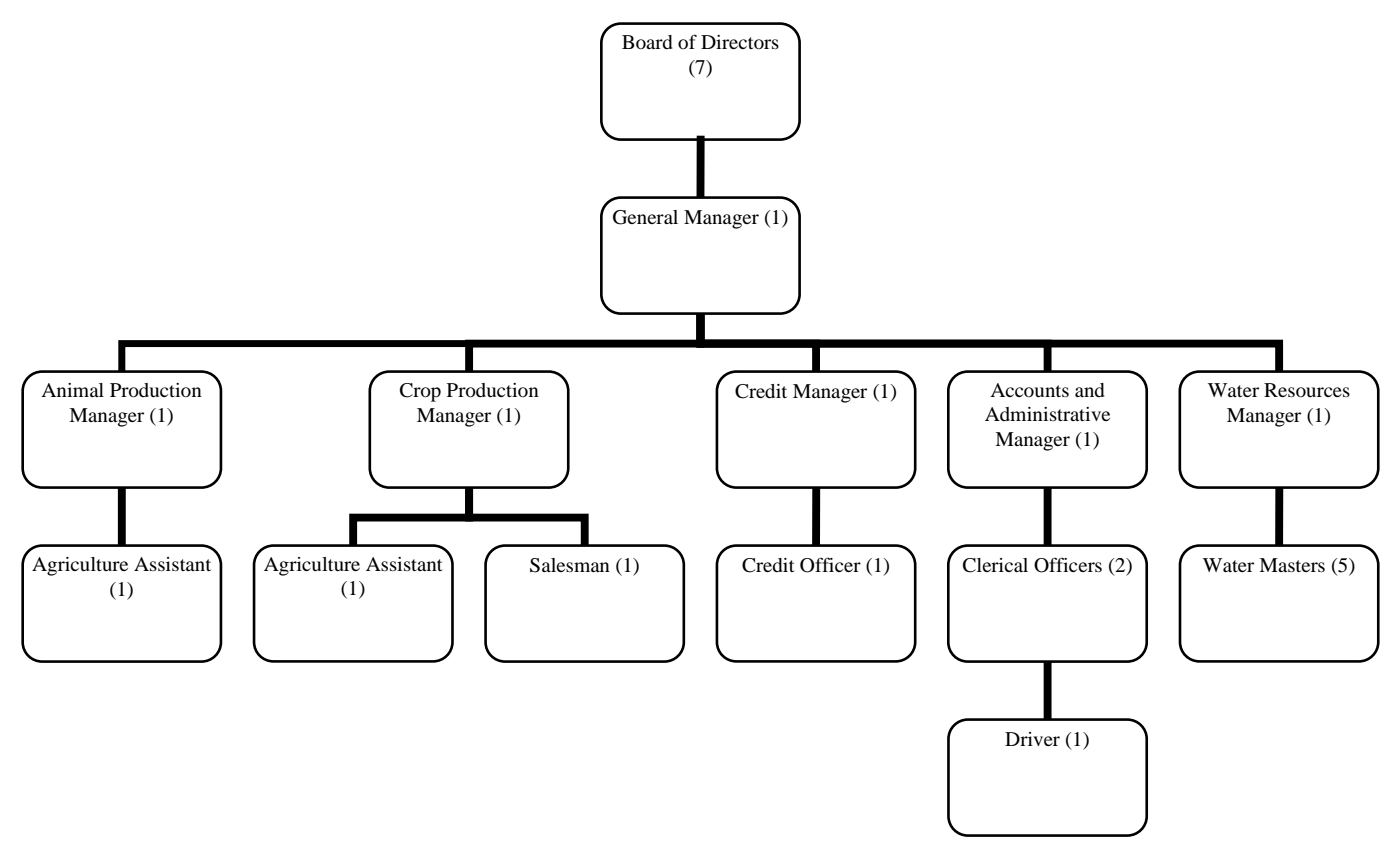

Figure 01: Organizational structure of Ridi Bendi Ela Farmer Company

Table 03: Major commercial activities in the financial year 2003/2004

\begin{tabular}{|c|c|c|c|c|}
\hline Activity & $\begin{array}{l}\text { No of } \\
\text { farmers } \\
\text { involved }\end{array}$ & $\begin{array}{l}\text { Amount distributed/ } \\
\text { Quantity produced }\end{array}$ & $\begin{array}{l}\text { Revenue } \\
\text { (Rs.000’s) }\end{array}$ & Linkage partners \\
\hline Group loan & 1,035 & Rs 8.6 million & $1,364 *$ & - \\
\hline $\begin{array}{l}\text { Broiler } \\
\text { production }\end{array}$ & 83 & 115,000 birds/month & 947 & Ceylon Agro-Industries \\
\hline Seed paddy & 83 & $\begin{array}{l}\text { Rs } 0.7 \text { million } \\
144 \mathrm{MT} / \text { season }\end{array}$ & 5,068 & Agrarian service centers \\
\hline Basmati (Rice) & 35 & 39 MT/season & 1,284 & $\begin{array}{l}\text { Cargills supermarket } \\
\text { chain }\end{array}$ \\
\hline Vegetable seeds & 25 & - & 514 & - \\
\hline Maize & 30 & - & - & Ceylon Agro-Industries \\
\hline Dairy /livestock & 20 & 20 cows & - & - \\
\hline $\begin{array}{l}\text { Agricultural } \\
\text { inputs sales }\end{array}$ & - & - & 14,783 & Many input suppliers \\
\hline
\end{tabular}

(Note) *: this value is the interest received from the group loan program.

Table 04: Group loan program

\begin{tabular}{ccccc}
\hline $\begin{array}{l}\text { Cultivation } \\
\text { Season }\end{array}$ & $\begin{array}{c}\text { Number of } \\
\text { Farmers }\end{array}$ & $\begin{array}{c}\text { Amount of loan distributed } \\
\text { (Rs. Millions) }\end{array}$ & $\begin{array}{c}\text { Recovery rate } \\
\text { (\%) }\end{array}$ & $\begin{array}{c}\text { Profit } \\
\text { (Rs. 000’s) }\end{array}$ \\
\hline $1999 / 2000$ & 549 & 3.25 & 79 & 422 \\
$2000 / 2001$ & 777 & 4.26 & 80 & 946 \\
$2001 / 2002$ & 853 & 5.44 & 80 & 1,273 \\
$2002 / 2003$ & 928 & 7.16 & 83 & 1,583 \\
$2003 / 2004$ & 1,035 & 8.60 & 84 & 1,364 \\
\hline
\end{tabular}




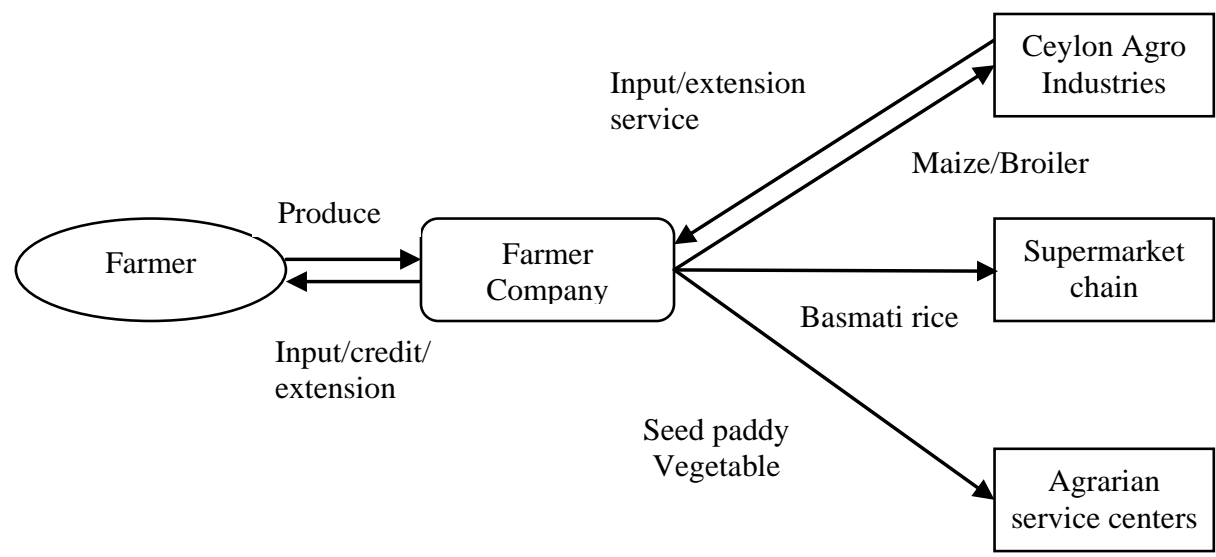

Figure 02: Farmers-agribusiness linkages arranged by the farmer company

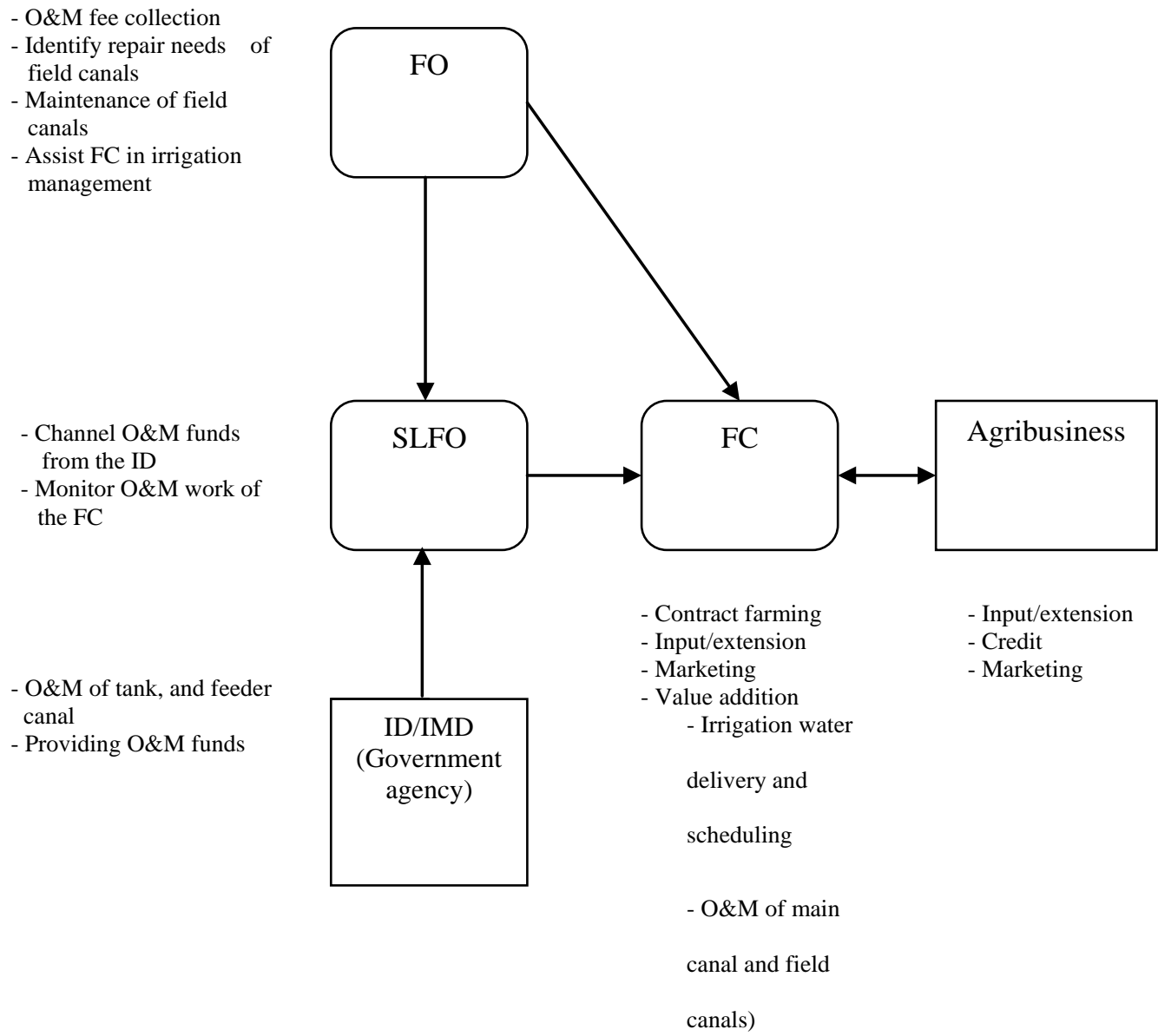

Figure 03: Relationships and roles of various organizations in the Ridi Bendi Ela irrigation scheme

Note) FC- Farmer Company, FO-Farmer Organization, SLFO- System Level

Farmer Organization, ID-Irrigation Department and IMD-Irrigation Management Division 


\section{(3) Irrigation management}

The farmer company is responsible for the operation and maintenance (O\&M) of the irrigation system below the main sluices of the dam, while the Irrigation Department (ID) is responsible for the O\&M of the tank and feeder canal. The water resource management section undertakes the responsibility of irrigation scheduling and O\&M with the assistance of 11 farmer organizations and the system level farmer organization (SLFO). These 11 farmer organizations represent a field canal or portion of a field canal. The legal farmers cultivating in the command areas of each field canal are members of these farmer organizations. The farmer organizations are responsible for identifying repair needs of the field canals, to assist the company in carrying out maintenance work and collect O\&M fees from farmers. There are instances where the farmer company contracts out cleaning of main canals to the farmer organizations. The SLFO is composed of the farmer representatives and acts as an intermediary in transferring operation and maintenance funds to the company since regulations do not permit direct transfer of government funds to a private organization like a farmer company. Moreover, the SLFO monitors the use of these funds by the farmer company. SLFO can be considered as a single organization representing the 11 farmer organizations (Figure 03). Irrigation scheduling, water issue and operation and maintenance matters are discussed at the pre-cultivation (Kanna) meetings implemented by the company, involving SLFO members, farmer company officials and ID/IMD officials. Except farmer organization meetings being used as a forum to promote farmer company activities, most of these organizations involve only in irrigation management activities.

\section{Performances}

As shown in Table 05, a farm level survey carried out by the Irrigation Water Management Institute (IWMI) revealed that most of the irrigation problems experienced by farmers in the Yala season have been minimized after the company took over the operation and maintenance responsibility (Hussain and Perera, 2004).

Table 06 provides a summary of company objectives and the extent to which these objectives have been achieved. The company has made significant progress in irrigation management. However, commercialization of agriculture in the scheme, particularly value addition, market facilitation and facilitation of farmers-agribusiness linkages have shown modest progress.

The turnover of the company has grown over the past six years except for a small drop in the 2001/2002 financial year (Table 07). The company reported operating losses for the first three financial years. However, the performance has since improved with operating profits increasing in the last three financial years. The initial losses of the company were covered by government grants, which were made available until 2001/2002. From 2001/2002, the company has become financially profitable and the government grant is not available any more. However, profitability has slightly declined in the last two years due to the increase in volume of activities, which increased 
by $160 \%$ from $1999 / 2000$ to 2003/2004, particularly the sale of agricultural inputs including seed paddy, fertilizer and agrochemicals at low profit margins. With regard to management performance, the ratio of return on capital employed (ROCE) or the effectiveness of the assets that are financed by the long term lenders and shareholders, has improved over time and at present stands at around $20 \%$. The current ratio commonly used to measure the liquidity position of the company is at an acceptable level of $1.6: 1$, although it has declined over time with the increase in volume of activities. Since the company started making profits in the last three financial years, it has been able to reward the farmer shareholders by issuing bonus shares. For instance, in the 2002/2003 financial year one bonus share was issued for every five shares owned and in the 2003/2004 financial year 2.28 shares were issued for every 10 shares owned.

\section{Farmer Shareholders' Perception and Awareness}

Among the farmer shareholders surveyed, 55\% (17 out of the effective 31 farmers in total) were active shareholders involved in at least one commercial activity organized by the Ridi Bendi Ela Farmer Company. Comparison of farmer shareholders' perception and awareness of the Farmer Company between active and passive shareholders is presented in Table 08.

There was no significant difference between the two groups with regard to their perception on the Ridi Bendi Ela Farmer Company as a service providing organization and their expectation of dividends, being as high as $94 \%$ and $87 \%$ respectively. On the other hand, given the many organizations in the irrigation scheme, the absolutely low 35\% of the respondents had a clear idea about the role of the farmer company, yet there was a significant difference between the two groups. Moreover, there was a contrasting level of satisfaction with irrigation management (74\%) and commercialization of agriculture (29\%). Participation in the annual general meetings was significantly different between the two groups, being relatively high (59\%) for the active shareholders and low (21\%) for the passive shareholders.

Regarding the commercial activities of the Ridi Bendi Ela Farmer Company, all of the farmers were aware of the group loan program and inputs sales by the farmer company, while the awareness of the other activities such as seed paddy production and broiler production was limited. It was especially interesting that such a low level of awareness was common to both active and passive shareholders.

\section{Issues from the Case Study}

Herein, issues arising from the aspects of farmer perception, farmer company management and performance are discussed from the viewpoint of improving the Ridi Bendi Ela Farmer Company.

In Sri Lanka, farmers are accustomed to viewing institutions supporting farming as service providers rather than business enterprises. It was not different in the case of Ridi Bendi Ela Farmer Company as majority of farmer shareholders perceived the company as a service providing organization. They did not expect any dividends for their investments and consider their investment in shares as a mere subscription for accessing the services provided by the company. As a result 
many farmers just own the minimum number of shares to have access to the services provided by the company. For instance, to obtain a group loan it is necessary to own a minimum of 25 shares. As shown in Figure 4, about $81 \%$ of the shareholders own up to 30 shares while only $3 \%$ of shareholders own 100 or more shares. It is clear that majority of farmers have become shareholders to obtain group loan. Furthermore, majority of farmers believe that the company should neither charge a fee for coordinating farmers-agribusiness linkages nor charge a market-based interest rate for farmer credit. This situation can have far reaching implications on the capital base as well as the business orientation of the company.

Table 05: Irrigation problems before and after the formation of the farmer company

\begin{tabular}{lcccc}
\hline \multirow{2}{*}{ Problem } & \multicolumn{2}{c}{ Before } & \multicolumn{2}{c}{ After } \\
\cline { 2 - 5 } & Yala* & Percentage & Yala* & Percentage \\
\hline Inadequacy & 27 & 19 & 15 & 11 \\
Timeliness & 8 & 6 & 1 & 1 \\
Unreliability & 4 & 3 & 2 & 1 \\
Water stealing & 19 & 14 & 8 & 6 \\
Violation of rotation & 10 & 7 & 3 & 2 \\
Water wastage & 23 & 16 & 6 & 4 \\
Structure problems & 7 & 5 & 6 & 4 \\
Total & 98 & 70 & 41 & 29 \\
\hline
\end{tabular}

Source: Hussain and Perera (2004).

Note)*: number of farmers.

Table 06: Company objectives and achievements

\begin{tabular}{|c|c|}
\hline Objective & What is achieved so far \\
\hline \multicolumn{2}{|l|}{ Commercialization } \\
\hline $\begin{array}{l}\text { Farmer participation in } \\
\text { farmer company }\end{array}$ & $\begin{array}{l}\text { About } 80 \% \text { of the families living in the irrigation } \\
\text { scheme are members of the farmer company }\end{array}$ \\
\hline Input supply & Input needs of about 1,000 ha ( $40 \%)$ is covered \\
\hline Credit supply & $\begin{array}{l}\text { About } 30 \% \text { of the farmers in the scheme are able to } \\
\text { obtain credit }\end{array}$ \\
\hline Value addition & $\begin{array}{l}\text { No significant activities to add value to products in the } \\
\text { scheme have been initiated }\end{array}$ \\
\hline Facilitate marketing & $\begin{array}{l}\text { No significant progress in facilitating marketing of farm } \\
\text { products produced by farmers in the scheme }\end{array}$ \\
\hline Extension/Training & $\begin{array}{l}\text { The company is covering extension needs of about } 30 \% \\
\text { of farmers in the scheme in crop and livestock } \\
\text { production }\end{array}$ \\
\hline Private sector participation & $\begin{array}{l}\text { Private sector participation is limited as only about } 10 \% \\
\text { farmers are involved in farmers-agribusiness linkages }\end{array}$ \\
\hline \multicolumn{2}{|l|}{ Irrigation Management } \\
\hline $\begin{array}{l}\text { Improvement in irrigation } \\
\text { water }\end{array}$ & $\begin{array}{l}\text { Irrigation problems like inadequacy, timeliness, } \\
\text { unreliability, water stealing, violation of rotation, water }\end{array}$ \\
\hline $\begin{array}{l}\text { efficiency/maintenance of } \\
\text { structures }\end{array}$ & $\begin{array}{l}\text { wastage and structural problems have been minimized. } \\
\text { Water use efficiency has improved from } 18,427 \mathrm{~m}^{3} / \text { ha to } \\
13,730 \mathrm{~m}^{3} \text { /ha }\end{array}$ \\
\hline
\end{tabular}


Table 07: Financial performances

\begin{tabular}{lcccccc}
\hline & $1998 / 1999$ & $1999 / 2000$ & $2000 / 2001$ & $2001 / 2002$ & $2002 / 2003$ & $2003 / 2004$ \\
\hline $\begin{array}{l}\text { Turnover } \\
\text { Operating profit/ }\end{array}$ & 1,334 & 8,858 & 13,679 & 12,900 & 22,209 & 23,103 \\
(Loss) & $(556)$ & $(173)$ & $(311)$ & 1,674 & 3,241 & 4,190 \\
$\begin{array}{l}\text { Government grant } \\
\text { Share capital }\end{array}$ & 1,000 & 1,450 & 2,002 & 1,176 & 0 & 0 \\
Bonus share issue & 183 & 318 & 442 & 525 & 685 & 839 \\
Return on capital & - & - & - & - & $5: 1$ & $10: 2.28$ \\
Employed & -18.2 & -2.2 & -2.5 & 9.2 & 16.1 & 19.8 \\
Net profit margin* & -35.4 & -1.0 & -1.0 & 10.0 & 6.8 & 5.9 \\
Current ratio & 4.9 & 2.9 & 5.2 & 2.3 & 1.8 & 1.6 \\
\hline
\end{tabular}

Notes 1) All values in Rs 000's.

2) *: government grant is not included in the calculation of net profit margin.

Table 08: Farmer shareholders' perception in percentage

\begin{tabular}{|c|c|c|c|}
\hline Items & Total & $\begin{array}{l}\text { Active } \\
\text { shareholders }\end{array}$ & $\begin{array}{l}\text { Passive } \\
\text { shareholders }\end{array}$ \\
\hline Consider as a service provider & 94(29) & $89(15)$ & $100(14)$ \\
\hline Not expecting dividends & $87(27)$ & $88(15)$ & 86(12) \\
\hline $\begin{array}{l}\text { Understanding about the role } \\
\text { of } \\
\text { the farmer company }\end{array}$ & $35(11)$ & $47(8)^{* *}$ & $21(3)^{* *}$ \\
\hline $\begin{array}{l}\text { Satisfaction } \\
\text { commercialization } \\
\text { Of agriculture }\end{array}$ & 29(9) & $35(6)$ & 19(3) \\
\hline $\begin{array}{l}\text { Satisfaction with irrigation } \\
\text { Management }\end{array}$ & $74(23)$ & $71(12)$ & $79(11)$ \\
\hline $\begin{array}{l}\text { Participation in Annual general } \\
\text { meeting }\end{array}$ & $42(13)$ & $59(10)^{* *}$ & $21(3)^{* *}$ \\
\hline \multicolumn{4}{|l|}{ Awareness of activities } \\
\hline Group loan & $100(31)$ & 100(17) & 100(14) \\
\hline Input sales & $100(31)$ & 100(17) & $100(14)$ \\
\hline Seed paddy & 55(17) & $71(12)^{*}$ & $36(5)^{*}$ \\
\hline Broiler & $48(15)$ & $65(11)^{* *}$ & $29(4)^{* *}$ \\
\hline
\end{tabular}

Notes 1) Active shareholders are those who involve in at least one commercial activity of the farmer company except input purchases from the company.

2) Values in parentheses are the number of farmers.

3) *: significant at $10 \%$ level. **: significant at $5 \%$ level. 


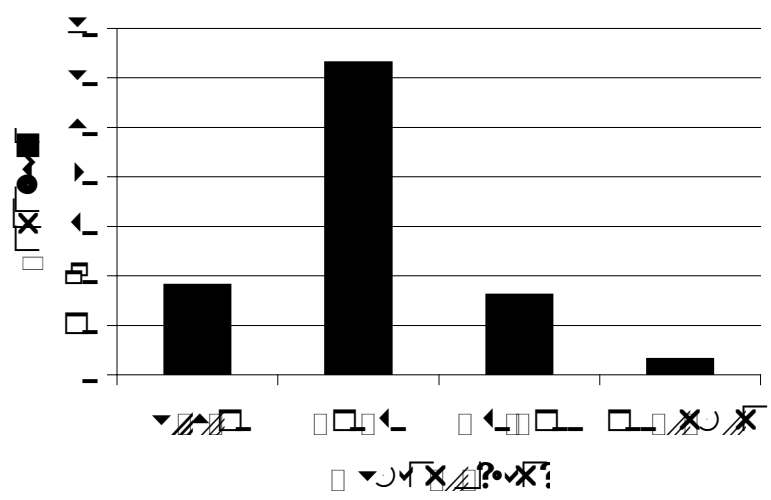

Figure 04: Distribution of shareholders by number of shares

There is an awareness/perception gap between the shareholders and the company, as many shareholders do not know the activities undertaken by the company. Although about $80 \%$ of farmer inhabitants in the irrigation scheme are shareholders of the company, only about $55 \%$ of the shareholders are involved in at least one commercial activity sponsored by the company. There is a need to get more farmers to actively participate in the activities by increasing farmer interests in and awareness of the company activities. Moreover, the roles of the company are not clear to many shareholders. For instance, there is a confusion regarding the role of the farmer company, as many believe that the farmer company has replaced the farmer organizations. It is important to define clearly and convey the role of the farmer company and farmer organizations in irrigation management and commercialization of agriculture. Active participation of the farmer organizations and SLFO should be sought not only in irrigation management but also in commercialization of agriculture as these farmer organizations are more closely involved in the affairs of the farmers.
Regarding commercialization of agriculture in the irrigation scheme, the Ridi Bendi Ela Farmer Company has achieved limited success in introducing new ventures relating to post-harvest, value addition, new crops and livestock. Apart from the group loan program, none of the other programs are carried out on a large scale. The farmer company is overly dependant on the group loan program to generate profits as more than 33\% of the total profit has come from this program.

The Ridi Bendi Ela Farmer Company has limitations in raising equity capital, as already $80 \%$ of the farmers living in the irrigation scheme are shareholders of the farmer company. On the one hand, despite the potential to increase the number of shares per farmer as at present only about 3\%of the shareholders own more than 100 shares, poor farmer awareness and farmer perception have made it difficult. On the other hand, restriction on share ownership has limited the prospects for expanding the share capital base outside the irrigation scheme to involve agribusiness industry and other farmers. Therefore, it is necessary to increase farmer awareness to encourage more farmer participation and relax the restriction on share ownership to enable 
agribusiness firms to own shares and actively participate in the activities of the farmer company. However, agribusiness industry participation should be sought cautiously to ensure the controlling interest of the farmer company remains with the farmers belonging to the irrigation scheme. This could be done by restricting the number of shares that can be owned by outsiders from the irrigation scheme to $20 \%$ to $30 \%$ of the total issued share capital.

\section{CONCLUSION}

Given the many constraints faced by farmer companies in commercializing agriculture, an attempt was made to review the potential of Ridi Bendi Ela Farmer Company in Sri Lanka on the aspects of farmer perception, management, and performance. The study revealed that the farmer company as a formal collective group has so far failed to achieve much with respect to commercialization of agriculture in the irrigation scheme due to two important issues. First, the farmers' perception of the farmer company as a service provider and the restrictions on share ownership by outsiders from the irrigation scheme has limited the capital necessary for expanding the commercial activities of the farmer company. Secondly, the awareness gap between the shareholders and the farmer company has resulted in poor farmer participation in commercial activities sponsored by the farmer company. Therefore, to improve the performance of the farmer company it is necessary to expand commercial activities to attract more farmer participation. This could be done through strengthening the capital base and organizing mutually beneficial farmersagribusiness linkages. The capital base of the farmer company can be strengthened through increasing the number of shares per farmer and relaxing the restrictions on share ownership from outside the irrigation scheme. However, to preserve the independence of the farmer company, the share ownership of the agribusiness industry in the farmer company should be limited to allow the farmers to have the controlling interest of the farmer company.

\section{References}

Batuwitage, G. (2001). Farmer Companies: Can they stand up Expectations in the Changing Economy? Paper presented at APO study meeting on agrarian reforms and agricultural productivity. Colombo, Sri Lanka.

Dunham, D. (1995). Contract Farming and Export Horticulture: Can Agribusiness Revitalise the Peasant Sector in Sri Lanka? IPS Agricultural Policy Series No. 3, Institute of Policy Studies, Colombo.

Esham, M. and K. Usami (2005). Present State and Issues of Farmers-agribusiness Linkages through Farmer Organization/Group in Sri Lanka: A Case Study of Hybrid Maize Production. Journal of Agricultural Development Studies, 16(2), pp. 27-36.

Esham, M., K. Usami, H. Kobayashi, and I. Matsumura (2006). An Economic Study of Contract Farming in the Fruit and Vegetable Industry in Sri Lanka: A Case Study of Gherkin (Cucumis sativus) Production, Journal of Rural Problems, 42(1), pp.14-23. 
Hussain, I. and L. R. Perera (2004). Improving Agricultural Productivity for Poverty Alleviation through Integrated Service Provision with Public Private Sector Partnerships: Examples and Issues, Working paper No. 66, International Water Management Institute. Colombo, Sri Lanka.

Little, P. D. and M. J. Watts (1994). Living Under Contract: Contract Farming and Agrarian Transformation in Sub Saharan Africa. The University of Wisconsin Press, Madison, London.

Porter, G. and K. Phillips-Howard (1995). Farmers, Labourers and the Company: Exploring Relationships on a Transkei Contract Farming Scheme. The Journal of Development Studies 32 (1), pp. 55-73.

Senanayake, M. S. (2004). What is ailing Farmer Companies of Sri Lanka in their Transformation into Successful Business Entities? Over view of Policy Issues, Paper presented at the 3rd International conference of the Japan Economic Policy Association at Meiji University, Japan.

Somaratne, W. G. and R. M. G. K. B. Ratnayake (2004). Contract Farming in Sri Lanka: Potential and Problems in Market Integration, Hector Kobbekaduwa Agrarian Research and Training Institute, Colombo.

Wijayaratna, C. M. (1997). Role of Farmer Companies in the Sri Lankan Rural Economy. Sri Lanka Journal of Agrarian Studies, 9, pp 69-83. 